\title{
SERAPAN TENAGA KERJA PADA BUDIDAYA IKAN PATIN DALAM KOLAM DI KABUPATEN BANJAR, KALIMANTAN SELATAN
}

\author{
LABOR ABSORPTION IN PATIN FISH CULTIVATION \\ IN POOLS IN BANJAR DISTRICT
}

\author{
Irma Febrianty \\ Universitas Lambung Mangkurat \\ irma.febrianty@ulm.ac.id
}

\begin{abstract}
The difference in pond area owned by catfish cultivators will result in differences in pond management so that the wider the pond, the more manpower needed and the worker specifications required by the cultivators. The purpose of this research is to see the labor absorption in catfish culture in ponds, as well as the labor value according to the specifications of the type of work required. The data analysis method uses descriptive analysis for the amount of labor absorbed and Oppurtunity cost, namely what benefits the workforce gets in working in catfish farming. Labor absorption in catfish farming in ponds for large scale businesses requires permanent labor to maintain the pond. as many as 4 people and harvest labor also requires as many as 8 9 people. Medium-scale businesses require 1-3 permanent workers and 5-7 panensian workers, while small scale businesses do not require permanent workers to maintain the pond because they are guarded by themselves and require 5-6 harvest workers. The value of the labor resources absorbed in catfish culture in the pond is $R p$. 436,608,000.00.
\end{abstract}

Keywords: Labor, Cultivation, Catfish.

\begin{abstract}
ABSTRAK
Perbedaan luas kolam yang dimiliki pembudidaya ikan patin akan mengakibatkan perbedaan dalam pengelolaan kolam sehingga semakin luas kolam semakin banyak tenaga kerja yang diperlukan dan spesifikasi pekerja yang diperlukan oleh pembudidaya. Tujuan dari penelitian ini untuk melihat serapan tenaga kerja pada usaha budidaya ikan patin di kolam, serta nilai tenaga kerja sesuai spesifikasi jenis pekerjaan yang diperlukan. Metode analisa data menggunakan analisis dekriptif untuk jumlah tenaga kerja yang terserap dan Oppurtunity cost yaitu manfaat apa yang diperoleh tenaga kerja dalam bekerja di usaha budidaya ikan patin.Serapan tenaga kerja di budidaya ikan patin dalam kolam untuk skala usaha besar memerlukan tenaga kerja tetap untuk menjaga kolamnya sebanyak 4 orang dan tenaga kerja panen juga memerlukan sebanyak yaitu 8 - 9 orang. Skala usaha sedang memerlukan $1-3$ orang tenaga kerja tetap dan 5-7 orang tenaga kerja panensedangkan skala usaha kecil tidak memerlukan tenaga kerja tetap untuk menjaga kolamnya karena dijaga sendiri dan memerlukan tenaga kerja panen sebanyak 5 - 6 orang. Nilai sumberdaya tenaga kerja yang terserap pada budidaya ikan patin dalam kolam sebesar Rp 436.608.000,00.
\end{abstract}

Kata Kunci: Tenaga Kerja, Budidaya, Ikan Patin. 


\section{PENDAHULUAN}

Usaha budidaya perikanan yang berkembang di masyarakat, baik sebagai mata pencaharian pokok atau matapencaharian sampingan memerlukan tenaga kerja dari luar, apalagi kalau kolam yang dimiliki banyak dan luas. Banyaknya kolam yang dimiliki pembudidaya beragam dari yang besar sampai yang keciltergantung dari modal yang dimiliki pembudidaya, jenis ikan yang dipelihara juga berbeda-beda pada umumnya ikan yang biasa dipelihara untuk budidaya adalahikan patin, mas dan nila.

Sumberdaya perikanan budidaya membawa peran penting sebagai penyedia sumber protein hewani disamping perikanan tangkap.Keberlanjutan usaha perikanan budidaya dipengaruhi oleh ketersediaan tenaga kerja perikanan budidaya yang berkompeten. Semakin luas lahan kolam yang dimiliki maka pembudidaya ikan tidak bisa mengelola sendiri kolamnya sehingga perlu bantuan orang lain. Hafidz (2019) dalam penelitiannya mengenai keperluan tenaga kerja dimana memproduksi ikan sebanyak 1 ton ikan diperlukan tenaga kerja berkisar 0,66 sampai 0,92 orang, sehingga dengan peningkatan produksi 349.000 ton akan terserap tenaga kerja pada perikanan budidaya sebanyak 370.000 orang.

Peningkatan produksi perikanan diasumsikan akan meningkatkan luasan areal budidaya air tawar seluas 12.301,22 Ha, atau secara intensif terjadi peningkatan produksi perikanan budidaya yang setara dengan produksi lahan seluas 12.301,22 Ha. Sedangkan untuk peningkatan luasan areal budidaya air payau seluas $51.255,1 \mathrm{Ha}$, atau secara intensif terjadi peningkatan produksi perikanan budidaya yang setara dengan produksi lahan seluas 51.255,1 Ha.

Kabupaten Banjar merupakan salah satu daerah penghasil ikan patin dari budidaya kolam dengan produksi ikan patin sebesar $11.717,2$ ton tahun 2016. (Dinas Perikanan dan Kelautan Kalimantan Selatan, 2017).Hasil penelitian Febrianty (2018), mengenai skala usaha budidaya kolam ikan patin di Kabupaten Banjar menghasilkan terdapat perbedaan luas dari kolam yang dimiliki pembudidaya ikan patin yang terbagi dalam 3 (tiga) skala usaha.Skala usaha responden di Kabupaten Banjar adalah skala usaha kecil 26 RTP $(57,77 \%)$ luas lahan $2-5$ ha, jumlah kolam yang dimiliki berkisar $2-8$ buah dengan luas kolam $\pm 1.500 \mathrm{~m}^{2}$, skala usaha sedang 17 RTP $(37,77 \%)$ dengan luas lahan $5000-15.000 \mathrm{~m}^{2}$ dengan jumlah kolam 3- 10 buah kolam dan luas kolam $\pm 3000 \mathrm{~m}^{2}$. dan skala usaha besar 2 RTP $(4,44 \%)$ dengan luas lahan 20 ha jumlah kolam yang dimiliki 15 18 buah kolam dengan luas kolam \pm $5.000 \mathrm{~m}^{2}$. dari 45 responden.

Perbedaan luas kolam yang dimiliki pembudidaya ikan patin akan mengakibatkan perbedaan dalam pengelolaan kolam sehingga semakin luas kolam semakin banyak tenaga kerja yang diperlukan dan spesifikasi pekerja yang diperlukan oleh pembudidaya.Muhammad \& Dwisetya (2013) dalam penelitiannya mengenai tenaga kerja dalam hal ini petani merupakan faktor penting dan perlu diperhitungkan dalam proses produksi produksi pertanian. Tenaga kerja yang digunakan harus mempunyai kualitas berpikir yang maju sehingga mampu mengadopsi inovasi-inovasi baru, terutama dalam menggunakan teknologi untuk pencapaian komoditas yang bagus sehingga memiliki nilai jual tinggi. Kendala di lapangan dimana pembudidaya memerlukan tenaga kerja 
untuk penjaga kolamnya kadang diambil dari tenaga kerja luar daerah lokasi pembudidaya karena mereka mengharapkan pekerja tersebut mempunyai pengetahuan dan keterampilan teknis budidaya ikan sedangkan di daerah budidaya mereka tidak menemukan tenaga kerja tersebut, Imran (2017) dalam hasil penelitiannya menunjukkan bahwa tingkat pendidikan, usia, pengalaman kerja dan jenis kelamin berpengaruh positif signifikan terhadap produktivitas tenaga kerja industri kecil. Tenaga kerja untuk panen biasanya diambil dari tenaga kerja lokal karena sifatnya tidak tetap dan diperlukan dalam jumlah banyak setiap panennya, berdasarkan hal ini perlu dilakukan penelitian berapa jumlah tenaga kerja yang terserap oleh budidaya ikan patin dalam kolam di Kabupaten Banjar Kalimantan Selatan.

Tujuan dari penelitian ini untuk melihat serapan tenaga kerja pada usaha budidaya ikan patin di kolam, serta nilai tenaga kerja sesuai spesifikasi jenis pekerjaan yang diperlukan.

\section{METODE PENELITIAN}

Penelitian ini menggunakan metode survei untuk mendapatkan data tentang fakta dan gejala terbaru dalam penelitian .Penelitian dilaksanakan Mei 2017 sampai Juli 2018. Tempat penelitian di Kecamatan Martapura Kota dan Martapura Barat di Kabupaten Banjar, dengan pertimbangan daerah tersebut merupakan sentra budidaya ikan patin dengan populasi pembudidaya sebanyak 90 RTP yang terdiri dari berbagai skala usaha (skala usaha besar, sedang dan kecil).Sampel diambil $10 \%$ dari masing-masing strata.

$$
\text { Pengambilan sampel }
$$

dilakukan dengan stratified purposive sampling yaitu dengan menstrata masing-masing skala usaha budidaya ikan patin. Skala usaha yang di strata adalah: skala usaha kecil 26 responden RTP, skala usaha sedang 17 responden RTP dan skala usaha besar 2 responden RTP. Penentuan skala usaha dilakukan berdasarkan luas unit usaha budidaya dan modal yang dimiliki petani pembudidaya.Metode analisa data dengan analisisdekriptif untuk jumlah tenaga kerja yang terserap dan Oppurtunity cost yaitu manfaat apa yang diperoleh tenaga kerja dalam bekerja di usaha budidaya ikan patin.

\section{HASIL DAN PEMBAHASAN}

Tenaga kerja yang bekerja di kolam budidaya ikan patin adalah tenaga kerja tetap sebagian besar diambil dari daerah luar lokasi budidaya dan ada juga di daerah lokasi budidaya, hal ini disebabkan tenaga kerja tetap yang diperlukan memiliki kompetensi atau keterampilan secara teknis budidaya ikan patin, sedangkan tenaga kerja lokal yang banyak diserap dalam usaha budidaya ikan patin dalam kolam terutama pada saat panen ikan karena memerlukan banyak tenaga kerja berkisar $5-9$ orang setiap panennya,menurut hasil penelitian Winarso (2014) menunjukkan bahwa dilihat dari aksesibilitas, peluang pekerjaan tenaga kerja dibidang pertanian tidak menggunakan tenaga kerja dari luar pertanian. Tenaga kerja pada umumnya berasal dari daerah setempat sebagai tenaga kerja dan jasa transportasi. Data hasil analisaserapan tenaga kerja di kolam budidaya ikan patin di Kabupaten Banjar dapat dilihat pada Tabel 1.

Tabel 1

Jumlah dan Nilai sumberdaya tenaga kerja Budidaya Ikan Patin di Kolam Tahun 2018

\begin{tabular}{lllll}
\hline No. & Skala & Jumlah & Rerata & Nilai \\
& usaha & tenaga & Jumlah & sumberdaya \\
& & kerja & Tenaga & tenaga kerja \\
& & (orang) & Kerja & $(\mathrm{Rp})$ \\
\hline
\end{tabular}




\begin{tabular}{lllll}
\hline & \multicolumn{3}{c}{ (orang) } \\
\hline 1. & $\begin{array}{l}\text { Skala } \\
\text { usaha } \\
\text { besar }\end{array}$ & 17 & $8-9$ & $114.000 .000,00$ \\
\hline 2. & $\begin{array}{l}\text { Skala } \\
\text { usaha }\end{array}$ & 85 & 5 & $174.000 .000,00$ \\
& sedang & & \\
\hline $3 . \quad \begin{array}{l}\text { Skala } \\
\text { usaha } \\
\text { kecil }\end{array}$ & $6-7$ & $148.608 .000,00$ \\
& Jumlah 261 & \\
\hline & & & $436.608 .000,00$ \\
\hline
\end{tabular}

Nilai sumberdaya tenaga kerja yang terserap pada budidaya ikan patin dalam kolam sebesar $\mathrm{Rp}$ 436.608.000,00. Data untuk tenaga kerja tetap yaitu penjaga kolam dihitung upah per bulan berkisar antara Rp $1.500 .000-2.000 .000 /$ bulan. Data untuk tenaga kerja tidak tetap atau tenaga kerja panen diperoleh dengan menghitung upah yang mereka peroleh setiap $1 \mathrm{~kg}$ ikan patin sebesar $\mathrm{Rp}$ 300,00, sehingga diperoleh nilai sumberdaya tenaga kerja lokal secara keseluruhan baik skala usaha besar, sedang dan kecil.

Nilai sumberdaya tertinggi pada skala usaha sedang hal ini disebabkan banyaknya tenaga kerja yang terserap dan tingginya produksi ikan patin.Serapan tertinggi perorangan jumlah tenaga kerja per unit usaha pada skala usaha besar karena skala usaha besar memerlukan tenaga kerja tetap untuk menjaga kolamnya sebanyak 4 orang dan tenaga kerja panen juga memerlukan banyak pekerja yaitu 8 - 9 orang. Skala usaha sedang memerlukan $1-3$ orang tenaga kerja tetap dan $5-$ 7 orang tenaga kerja panensedangkan skala usaha kecil tidak memerlukan tenaga kerja tetap untuk menjaga kolamnya karena dijaga sendiri dan memerlukan tenaga kerja panen sebanyak 5 - 6 orang.

$$
\text { Tarsa (2017) dalam }
$$

penelitiannya faktor-faktor yang mempengaruhi penyerapan tenaga kerja pada industri pengolahan ikan di Kota penelitian dimana variabel tingkat output berpengaruh positif dan signifikan secara statistik yaitu ada peningkatan tingkat output $(\mathrm{O})$ sebesar $1 \%$, maka penyerapan tenaga kerja pada industri kecil pengolahan ikan di Kota Bandar Lampung akan meningkat sebesar 0,258822 \% dengan anggapan variabel tingkat upah (W), dan variabel modal kerja (M) adalah konstan. Suwartapradpa (2012), Serapan tenaga kerja pada budi daya perikanan perairan waduk dengan sistem KJA sebanyak 297 HOK tiap ha lebih banyak dibandingkan dengan serapan tenaga kerja pada pertanian lahan basah,sebelum waduk Cirata digunakan yaitu sebanyak 201 HOK tiap ha.

Dewi (2016) Hasil penelitian menemukan bahwa perkembangan penyerapan tenaga kerja sektor pertanian dengan rata-rata sebesar $8,06 \%$, kontribusi sektor pertanian terhadap penyerapan tenaga kerja total dengan rata-rata sebesar $62,48 \%$, faktorfaktor yang mempengaruhi peneyrapan tenaga kerja pada sektor pertanian yang terdiri dari pertumbuhan PDRB sektor pertanian dengan rata-rata $8,14 \%$, potensi luas lahan dengan rata-rata $5,22 \%$, upah minimum provinsi dengan rata-rata $15,89 \%$, investasi dengan ratarata 12,08 dan elastisitas penyerapan tenaga kerja pada sektor pertanian bersifat elastis yaitu sebesar $1,12 \%$.

Hasil penelitian ini berbeda dengan penelitian sebelumnya karena serapan tenaga kerja dilihat dari berbagai skala usaha yaitu skala usaha kecil, sedang dan besar sehingga dapat dilihat keperluan tenaga kerja berdasarkan skala usaha yang diusahakan dimana semakin besar skala usaha semakin banyak tenaga kerja yang terserap, hal ini untuk memberikan informasi kepada masyarakat dalam 
penentuan besarnya skala usaha yang mau mereka usahakan dan berapa jumlah tenaga kerja yang diperlukan. Skala usaha akan mempengaruhi besar kecilnya jumlah tenaga kerja yang dibutuhkan dan pula menentukan macam tenaga kerja yang bagaimana diperlukan.

Berbeda dengan hasil penelitian Hafidh (2019) menunjukkan analisis model regresi linier berganda terhadap model empiris diperoleh nilai koefisien regresi masing-masing variabel bebas pada pertanian padi sawah di Kecamatan Rowosari yaitu variabel tenaga kerja (TK), modal (M) dan luas lahan (LL) berpengaruh positif terhadap produksi usahatani padi sawah (PUP). Hasil penelitian Hafidz (2013) faktorfaktor yang mempengaruhi keputusan individu untuk bekerja pada kegiatan pertanian antara lain : kepemilikan lahan, pengalaman bertani, pendidikan, usia dan dan pendapatan

\section{PENUTUP}

\section{Kesimpulan}

Serapan tenaga kerja di budidaya ikan patin dalam kolam untuk skala usaha besar memerlukan tenaga kerja tetap untuk menjaga kolamnya sebanyak 4 orang dan tenaga kerja panen sebanyak yaitu 8 - 9 orang. Skala usaha sedang memerlukan $1-3$ orang tenaga kerja tetap dan $5-7$ orang tenaga kerja panensedangkan skala usaha kecil tidak memerlukan tenaga kerja tetap untuk menjaga kolamnya karena dijaga sendiri dan memerlukan tenaga kerja panen sebanyak 5 - 6 orang. Nilai sumberdaya tenaga kerja yang terserap pada budidaya ikan patin dalam kolam sebesar Rp 436.608.000,00.

\section{Saran}

Perlunya peningkatan

keterampilan tenaga kerja terutama tenaga kerja tetap di daerah lokasi budidaya dalam teknis budidaya perikanan sehingga mampu meningkatkan produktivitasnya, karena selama ini sebagian besar tenaga kerja tetap yang mempunyai keterampilan di budidaya ikan diambil dari luar lokasi budidaya

\section{DAFTAR PUSTAKA.}

Dinas Perikanan dan Kelautan Propinsi Kalimantan Selatan. (2017). Laporan Tahunan.

Dewi, R., F, Purwaka, H.,P \& Jaya K.,E， (2016). Analisis Penyerapan Tenaga Kerja pada Sektor Pertanian di Kabupaten Tanjung Japung. Prodi Ekonomi Pembangunan Fak. Ekonomi dan Bisnis Universitas JambieJurnal Ekonomi Sumberdaya dan Lingkungan, 5(1)

Hafidh, M. (2019). Pengaruh Tenaga Kerja, Modal, dan Luas Lahan terhadap Produksi Usaha Tani Padi (Studi kasus Di Kecamatan Rowosari Kabupaten Kendal).Skripsi. Jurusan Ekonomi Pembangunan. Fakultas Ekonomi. Universitas Negeri Semarang.

Imran, U. (2017). Faktor-Faktor Yang Mempengaruhi Produtivitas Tenaga Kerja Industri Kecil Kota Palopo. Journal of Islamic Education Management, 2(2): $187-198$.

Febrianty, I, Emmy, S.,M, \& Alim B., F. (2018). The economies of catfish pond culture in Banjar Regency, South Kalimantan. Jounal of Biodiversity Environmental Sciences (JBES), 13(1)

Muhammad, K \& Dwisetia, P. (2013). Faktor-Faktor Yang Mempengaruhi Keputusan Tenaga Kerja Untuk Bekerja di 
Kegiatan Pertanian (Studi Kasus : Kabupaten Rembang). Journal of Economics, 2(2):1-13.

Tarsa, A., N. (2017). Faktor-faktor yang Mempengaruhi Penyerapan Tenaga Kerja Pada Industri Kecil Pengolahan Ikan di Kabupaten Bandar Lampung Skripsi.Fakultas Ekonomi dan Bisnis Universitas Lampung.

Winarso, B (2014). Dinamika Ketenagakerjaan pada Wilayah Pedesaan Lahan Kering di Indonesia.Pusat Sosial Ekonomi dan Kebijakan Pertanian, Bogor. Jurnal Penelitian Pertanian Terapan 14(1): 1-14. 